\title{
STRATEGY FOR DEVELOPING INTEREST OF ENTREPRENEURSHIP THROUGH A CULINARY BUSINESS MANAGEMENT COURSE
}

\author{
Titin Hera Widi Handayani ${ }^{1}$, Sutriyati Purwanti ${ }^{2}$, Dewi Eka Murniati ${ }^{3}$, \\ and Safitri Yosita Ratri ${ }^{4}$ \\ 1,2,3Faculty of Engineering, Universitas Negeri Yogyakarta, Yogyakarta, Indonesia \\ ${ }^{4}$ University of Adelaide, Adelaide, Australia \\ E-mail: titin_hwh@uny.ac.id
}

\begin{abstract}
The objectives of this study were: (1) to determine the entrepreneurial interest of Diploma students in Culinary Engineering in Culinary Business Management (CBM) course, (2) to formulate strategies for developing students' entrepreneurial interest through the CBM course as recommendations for lectures in the next period. This ex post facto research with a descriptive approach was carried out in February to July 2019 in the Diploma Study Program of Culinary Engineering, Universitas Negeri Yogyakarta (UNY). The population of the study consisted of 40 students who took CBM in the odd semester of the 2018/2019 academic year. A purposive sampling technique was employed while the questionnaire was used in the data collection. Quantitative descriptive was used to analyze the data. The results show that: (1) Entrepreneurial interest of Diploma students of Culinary Engineering in the CBM course is $40 \%$ in the Very High category and $60 \%$ in the High category, (2) there are four strategies for developing students' entrepreneurial interest through the CBM course, namely SO (Strength-Opportunity) strategy: while WO (Weakness-Opportunity) strategy, ST (Weakness-Opportunity) strategy, and WT (Weakness-Threat) strategy. The benefits of this study are firstly, for students, it investigates students' entrepreneurial interests through learning CBM, for education staff, it examines the effectiveness of learning CBM in forming students' entrepreneurial interests, and for educational institutions, it is an effort to evaluate and recommend learning CBM to form students' entrepreneurship.
\end{abstract}

Keywords: culinary business management course, development strategy, entrepreneurship interest

\section{INTRODUCTION}

Entrepreneurship education for the young generation is important for several reasons. Firstly, there are currently too many job seekers and too few job creators and vacancies. Recent data from the Central Bureau of Statistics shows that the unemployment level in Indonesia is still high, with $5.13 \%$, although there is a $0.2 \%$ decrease compared to last year [1]. The irony lies in that unemployment is dominated by graduates of vocational high school [2] in the first place $(8.92 \%)$, followed by university graduates (mainly from the vocational degree) with $7.92 \%$. Secondly, the total growth of entrepreneurs will result in wider social welfare. This is because entrepreneurs are more independent in running their business, hardly affected by inflation, and able to create jobs for the community. Thirdly, as a country with abundant natural resources, it is crucial that Indonesia has entrepreneur human resources to manage the natural resources for the welfare of the nation and state. True entrepreneurs not only possess creativeinnovative senses, but they are also lifelong seekers of opportunity who are willing to take measured risks and believe that customer service is the key to success. With the entrepreneurship mindset, character, and skills, the youth of Indonesia will no longer become dependent on any jobs or rely on the government or other people to prosper.

One of the benchmarks of the success of a country's economy is the quantitative number of business owners in the country. 
In 2013, the number of business owners in Indonesia is still below $2 \%$, which is the minimum number for developed countries [3]. Despite an increase of $3.1 \%$ in 2018 , Indonesia remains behind the neighboring countries such as Singapore [4], Thailand, and Malaysia [5]. In the world ranking, Indonesia is placed 94 among 137 countries, which is way below other ASEAN countries such as Singapore, Malaysia, Thailand, and the Philippines, which rank 27, 58, 71, and 84 , respectively. This suggests a low level of entrepreneurship in Indonesia. The Ministry affirms that the education system is one of the main contributing factors for the low level of entrepreneurship, which hinders the students' ability to develop [5]. The Ministry of Research, Technology, and Higher Education states that the high level of unemployment among university graduates and the low level of workforce absorbency [6] is due to the assumption that having a business does not make a promising career. As a result, university graduates tend to fight for vacancies in various corporations rather than use and apply their knowledge to create their occupation.

Entrepreneurship education has been recognized as one of the contributing factors in helping the young generation understand and develop entrepreneurship behavior [7] Therefore, there needs to be a deeper understanding of how to develop and nurture the entrepreneurial interest and potential at the school level. Entrepreneurship is a source of innovation, job creation, and economic growth, as such it is pivotal to attract the young and the educated to become entrepreneurs. The goal of entrepreneurship education is to prepare students for entrepreneurial practice and to develop profound entrepreneurial competences [8]. In the experience of education, student will become self-directed learners [9]. Undergraduates are an important source of nascent entrepreneurs in the future and consequently, it is interesting to explore their intention for opportunity entrepreneurship [10].

Recognizing the importance of entrepreneurship in economic development in Indonesia, various efforts have been taken to teach entrepreneurship in schools and universities to fulfill the goal of creating graduates who have entrepreneurial character and motivation. Therefore, higher education institutions have a major contribution in developing entrepreneurial talents among young graduates. It is important to understand entrepreneurial education approaches to teach new business development or business plan preparation, including an integrated curriculum covering marketing, finance, competition analysis, and business plan development [11]. Skills and competencies are very important to produce entrepreneurial behavior [12]

The following are factors that can develop a positive mental attitude [13], namely: (1) using the mind productively, (2) staying away from negative thoughts and ideas, (3) choosing positive goals, (4) having the courage to develop ideas. positive ideas and goals, (5) self-confidence in their abilities and always trying to improve their abilities, (6) get rid of mental burdens, and be oriented towards positive actions. Entrepreneurial attitudes are reflected in the characteristics of quality modern humans, such as (1) being open to new experiences, (2) always reading social changes, (3) being more realistic about facts and opinions, (4) oriented towards the future. in the future, (5) planning, (6) confident, (7) having aspirations, (8) being educated and having expertise [14].

Entrepreneurship education is vital for providing and supporting the competencies 
of university graduates, especially those from Teacher Training Institutions. This is in line with the Government Regulation on how Higher Education Institutions shall produce graduates from various professions with the aims to (1) develop individuals who are (a) pious and devoted to God Almighty, virtuous, and have upstanding personality; (b) healthy, knowledgeable, and skilled; (c) critical, creative, innovative, independent, confident, and possess an entrepreneurial spirit; and (d) tolerant, socially and environmentally sensitive, democratic, and accountable; and (2) generate the products of science, technology, arts, or sports that are beneficial for the society, nation, state, humankind, and environment. This is supported by the characters of entrepreneurship as someone who has selfconfidence, has the orientation of tasks and results, is brave to take risks, has leadership ability, and has vision and authenticity [15].

The focus of entrepreneurship education is to develop an interest and will in running a business before actually making a start. Personal commitment plays a role in building a new business, and it is rooted in the interest and willingness in entrepreneurship [16]. The definition of interest is the feeling of attraction or fondness of a certain thing or activity, without coercion. Essentially, interest refers to an acceptance of the relationship with one's self and the things outside the self [17]. Winkel describes interest as an individual's consistent tendency to be engrossed in a certain field of study or matter and the feeling of joy in studying the material [18]. Entrepreneurial interest as the exploration and assessment of information which contributes to the achievement of business goals [16], [19], [20].

Entrepreneurship education at the school level, or in this case the university, is highly important to implement as an effort in developing entrepreneurship among the young generation. The university, which represents higher education, has an irreplaceable role in creating the culture of entrepreneurship in Indonesia. The first reason is that the campus serves as the main starting point for the educated youth into the employment market. Secondly, the campus is a strategic place to develop human resources, and lastly, it also has several educators who are committed to develop the potential of the younger generation. This is following one of UNY's vision and missions, i.e. to produce independent students. Therefore, having an entrepreneurial spirit serves as one of the most important aspects to realize the goal. It must be noted that the number of business owners in Indonesia is merely $3 \%$, far below the developed countries, which at least have $14 \%$ [10]. The discussion result shows that entrepreneurship education is very important to be applied in universities in any department to produce graduates with an entrepreneurial mentality who can open employment opportunities to support the progress of the country's economy [21]. Entrepreneurship educational programs can also play role in attenuating the risk-averse attitude of students, by providing them with training to take calculated business risks, and by emphasizing the use of local role models (e.g. successful entrepreneurs) and local case studiest raise the students 'awareness of the upside opportunities of starting their businesses [22]. Entrepreneurship education can increase student awareness about careers that exist in the field of entrepreneurship [22]. In addition, students have started to realize that entrepreneurship is a future career opportunity that must be prepared early on [23]. 
The Diploma Study Program of Culinary Engineering at UNY is a vocational level education with practice courses that are based on the instilment of entrepreneurial spirit. Nevertheless, the Theories on Entrepreneurship theory course is still taught as one of the general basic courses in the curriculum of each education level and study program at UNY. One of the practice courses in the Diploma Study Program of Culinary Engineering is the Culinary Business Management (CBM) course. This course aims to provide students with a business experience through a production-based learning pattern, as well as to optimize business education. The production-based learning pattern follows principles that are commonly used in the workplace from the business point of view to present students with a real condition of the working world in the students' learning system.

Students will get market-oriented learning experiences because every thoughtful step is aimed at making financially profitable results. The students act as workers, so each of them has a certain position in the production process. They are asked to do different jobs in manufacturing worth-selling products.

Learning by providing entrepreneurial experiences is expected to make students stay in the condition in which they are demanded to produce something better than before. They are also demanded to improve their knowledge, skills, enthusiasm, and innovations from day to day to improve their works. Also, students need to literate to the innovations of technology in this moderns society that will be beneficial for their lives to become better functioning individuals within their local and global communities [24]. Learning by doing is carried out by the students through the production process. The approach used in this learning is based on the idea that students can effortlessly understand, remember, and make their cognitive, psychomotor, and affective competencies balance. The experience learning approach promotes students' habits in observing, measuring, trying, comparing, feeling, motivating, and showing different treatments for the same product. At the same time students will increase the frequency and confidence in culinary [25]. The course allow them to learn by exploring the process becomes a positive stepping stone that they can learn and change [26]. Thus, students can investigate the feasibility of running a business based on the experience gained. The entrepreneurship processes include all functions of activities and actions which are related to the gain of chances and creations of the business organization [3].

Through this learning model, students become entrepreneurs in the context of learning that is emphasized on entrepreneurship. This idea is the implementation or application of competency-based learning focusing on things that students may do as a result of learning.

In CBM, students' entrepreneurship attitudes are analyzed through business education as the form of competency-based learning implementation where simulation is done. The students try to run a business in groups, predicting business opportunities through market analysis as well as the feasibility of selling the products or services, planning all resources needed for starting or running a business including analyzing capital, sources of funds, human resources, and market target optimization.

CBM is one of the courses expected to provide major impacts on building students' entrepreneurial interests. This practicum course is completed in two weeks so that the 
students have chances to run a business following the developed business plan. Therefore, the SWOT analysis (Strength, Weakness, Opportunity, and Threat) needs to be made at first to check all the learning instruments, namely learning structure, curriculum, lectures, learning media and method, lecturer's competence, student's activity, learning facilities, and realia. A strategy was then designed to improve students' entrepreneurial skills.

\section{METHOD}

This ex-post-facto study employed a descriptive approach. The research was conducted from February to July 2019 in the Diploma Study Program of Culinary Engineering, Department of Fashion Design and Culinary Engineering Education, Universitas Negeri Yogyakarta. This study involved forty students who had taken the CBM course in the odd semester of the

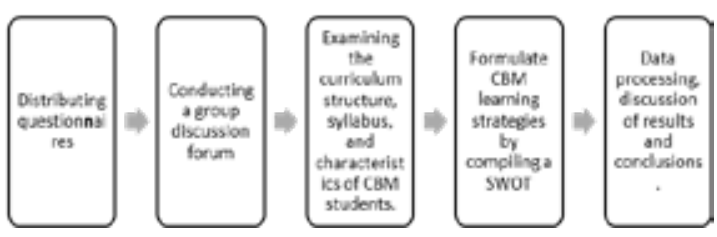

2018/2019 academic year. The sample was collected using purposive sampling. The data were obtained through a survey and then the quantitative descriptive approach was employed in the analysis. Research procedures carried out are presented in Figure 1.

Figure 1. The Diagram of Research Procedures

\section{RESULTS AND DISCUSSION}

The Students' Entrepreneurial Interests in CBM Learning can be seen in Table 1.
Table 1. The Percentage of Students' Entrepreneurial Interests in the CBM Course

\begin{tabular}{cccc}
\hline Score Interval & Category & Frequency & Percentage \\
\hline $\mathrm{x} \geq 113.7$ & Very High & 16 & $40 \%$ \\
$93.9 \leq \mathrm{x}<113.7$ & High & 24 & $60 \%$ \\
$74.1 \leq \mathrm{x}<93.9$ & Moderate & 0 & $0 \%$ \\
$54.3 \leq \mathrm{x}<74.1$ & Low & 0 & $0 \%$ \\
$\mathrm{x}<54.3$ & Very Low & 0 & $0 \%$ \\
Total & & 40 & $100 \%$ \\
\hline
\end{tabular}

Table 1 shows the Diploma in Culinary Engineering students' interest category in the CBM course. As many as 16 students or $40 \%$ are in the Very High category, 24 or $60 \%$ are in the High category, none or $0 \%$ is in the Moderate category, none or $0 \%$ is in a Low category, and none or $0 \%$ is in the Very Low category. Strategies for developing students' entrepreneurial interests in Diploma in Culinary Engineering are based on the SO (Strength-Opportunity) strategy which provides students with chances to develop their ideas and creativity as well as to improve their self-discipline. Moreover, this strategy provides them opportunities, trust, and responsibilities for managing a business in culinary and then evaluate it after the CBM course ends.

\section{Students' Entrepreneurial Interest}

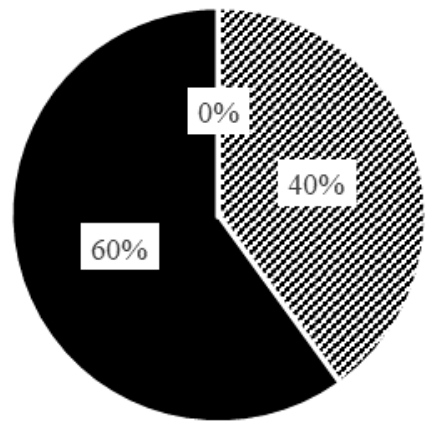

$$
\begin{array}{ll}
* \text { Very high } & \text { - High } \quad \text { Acceptable } \\
& \text { Low } \quad \text { - Very low }
\end{array}
$$

Figure 2. The Diagram of Students' Interest Category in CBM Course 
The WO (Weakness-Opportunity) strategy provides each student with opportunities to lead the business while conducting the CBM practices. This strategy trains the students to be brave in taking the risks of previously made decisions made by groups or individuals. It also trains the students to welcome both negative and positive criticisms or suggestions so that they can accept all the criticisms and suggestions proportionally. Meanwhile, the ST (Strength-Threat) strategy provides students with knowledge of financial business management and the understanding that theories may support CBM learning and that all courses in the study program are designed to provide them with competencies in Culinary Engineering. At last, the WT (Weakness-Threat) strategy tries to reconsider providing additional materials on leadership by creating leadership training and improving students' confidence by discussing several problems faced during the practicum, giving tasks to survey and observe a culinary business regarding business and financial management so that the students have a real idea about how to manage a business.

Culinary Business Management is a culmination of courses that the students have previously taken. This two-week course is a place where students set up a culinary business in groups. During the four meetings at the beginning of the lecture, students have an opportunity to conduct field observations (culinary business/restaurants in the campus surroundings), make a business plan, and present it in front of the class. For this project, each student is expected to be proactive to contribute their ideas in planning the business and its technical implementation. Students are given the capital cost to realize the plans made. The practice of running a business starts at the seventh meeting of the block-system lecture for two weeks. Based on the questionnaire data, it is known that the entrepreneurial interest of students in the Diploma Study Program of Culinary Engineering is high. It is because the students at the very beginning have completely known the vision and missions of the study program, one of which is to produce culinary entrepreneurs. However, some students may opine that taking the CBM course is a matter of obligation stated in the curriculum.

Regarding the results of the study, the student entrepreneurial interest is influenced by several factors. The most powerful factor in growing the entrepreneurial interest is dominated by the entrepreneurial awareness integrated into CBM learning activities which have significance for the development of the culinary competencies or personal development. This can be indicated by the high awareness sub-factor of the CBM learning significance in practicing competencies and skills in the production and service sectors for consumers.

The second strongest factor is specific awareness to be interested in entrepreneurial activities, which is dominated by concern that CBM learning has significance for future careers. In addition, students also realize that learning $\mathrm{CBM}$ teaches the students persistence to deal with sales decrease due to unsold products, complaints from consumers, and a low number of consumers. CBM learning is carried out in the Department of Fashion Design and Culinary Engineering Education, Faculty of Engineering, UNY campus, which offers positive or negative things. The positive thing is that there is a clear market share, namely the Department of Fashion Design and Culinary Engineering Education internal students or other majors in the Faculty of Engineering, UNY. Even so, consumers for 
CBM learning are still unpredictable, so that sales can be higher or lower. Another negative thing is the presence of other competitors in the campus environment. In the majority, the menus offered through CBM learning do not include fast food. This is the reason why they require a longer time for production and presentation. Whereas students often do not have enough time to rest in their break time, so other food sellers who can serve food more quickly become the solution.

The intrinsic factor is the lowest aspect in developing student entrepreneurial interest which includes the courage to take risks, leadership, confidence, and creative ideas in carrying out CBM learning. In CBM learning, students are free to set business plans, including ideas, task division, division of personnel and groups, variations in the menu, pricing, production flow, promotion, and distribution of sales. However, not all students have been able to convey their creative ideas, take part in business leadership, feel confident in their product, and communicate with consumers. This is indicated in the results of the study that the willingness to be the leader of the group is the lowest score dealing with the factor of student entrepreneurial interest. In addition, students are less motivated to be entrepreneurs, if they only attend the theory class.

According to the students, learning practices strongly support their interests. This needs to be a concern for lecturers to be able to wrap the theoretical learning better to meet practical learning needs. Also, students should be accommodated to integrate the knowledge and skills obtained in CBM learning. Although the intrinsic factor is the lowest aspect in the generating student entrepreneurial interest, the aspiration to become a food entrepreneur as the subfactor is the most powerful factor that underlies the student entrepreneurial interest. This is consistent with the theory stated by Katz \& Gartner that entrepreneurial interest has a role as a means of finding information and initiating motivation that a person goes through before starting a business, and it is an important factor to establish a business [23], [27]. In line with this, convey that individual entrepreneurial interests and intentions are important variables for predicting entrepreneurial behavior [21].

Students' general attitude factors which include feelings of like or dislike, agree or disagree, and positive or negative attitudes towards entrepreneurial activities in CBM learning contribute to foster entrepreneurial interest better than intrinsic factors. In general, students enjoy all activities in CBM learning, including collaboration, project discussion, and evaluation after CBM learning practices. Students also positively welcome the CBM learning system which is implemented in a 2-week block system that supports the exploration of business ideas and the manifestation of culinary competence actualization more optimally than the nonblock system. In addition, the initial capital loan for the start-up of the CBM business implementation also receives a positive response from the students. However, the score of other sub-factors in this general attitude is included in the low category, namely the sub-factor of the profit-sharing system in CBM learning.

The strategy to develop student entrepreneurial interest through Food Business Management Course is carried out using a SWOT analysis. As stated, the company's strategic decisions need to consider the internal factors including strengths and weaknesses, as well as external factors including opportunities, 
threats, and considerations important for the SWOT analysis [28].

In general, SWOT is intended to develop people's full awareness of any kind of situation so that it can advance their strategic planning and decision making. SWOT is not the only assessment technique to use, but it is the one with a long track record for knowing the effectiveness of a measure. The strength of this method is its simplicity and application at various levels of operations. This technique also allows a group or individuals to move from everyday problems to strategic problems [29]. There are four strategies formulated, namely: (1) SO (Strength-Opportunity), namely a strategy made by utilizing all the strengths to seize and take full advantage of opportunities, (2) ST (Strength-Threat), which is a strategy to use the strength they have to overcome threats, (3) WO (Weakness-Opportunity) a strategy implemented based on the utilization of the existing opportunities by minimizing the prevailing weaknesses, and (4) WT (Weakness-Threat), that is a strategy based on activities that are defensive and try to minimize the existing weaknesses and avoid threats.

In addition to the four strategies arranged, the previously observed condition in CBM learning are likely to reveal the following characteristics, among others: (1) students have the aspiration of being a great culinary entrepreneur, (2) they consider future careers and training in managing business and time, (3) they like developing ideas and creativity, being active and enthusiastic in learning, enjoying any good or bad experience, being cooperative, not easily discouraged, and sharing tasks. Additionally, (4) they are fond of activities in production, service, and learning atmosphere, but (5) having a lack of leadership, initiative, and confidence. They also (6) lack the courage to take risks, accept criticisms, and creative ideas, and (7) do not like capital loan system and profit-sharing. Besides, (8) the theory learning seems less appropriate to CBM learning. Based on these needs, several strategies should be chosen and implemented depending on the scale of the priority and various considerations that certainly cannot be separated from synergizing the various potential existing in CBM learning. Regarding this, SWOT analysis can be used as one of the alternatives in developing students' entrepreneurial interests, but to be effective, it should be done regularly since dynamic changes in the organization and environment make it difficult to anticipate SWOT development. Data used in the analysis can be based on assumptions rather than concrete evidence. However, SWOT does not have a detailed structure, so that important elements can undeniably be discounted [29].

By considering students' entrepreneurial interest in CBM learning, and SWOT analysis and matrix, the above strategies can be fully taken into account in developing their entrepreneurship spirit, by at the same time (1) encouraging strong commitment of the students and lecturer to develop their entrepreneurial interest and competency, (2) encouraging students' active participation in the planning, implementation, supervision, and evaluation of CBM learning, (3) carefully designing how theories should be delivered in the practical learning so that they enable students to integrate their knowledge and skills in CBM learning, and (4) giving students the understanding that CBM learning is not only about taking the course for credit requirement or course mark but also about their efforts to equip themselves 
with everything they need in their future career. This is in line with the results of research, entrepreneurship learning has a positive influence on fostering interest in entrepreneurship [30]. Entrepreneurship education does not only disseminate knowledge on entrepreneurship, yet, it also improves entrepreneurial attitudes and perceptions toward entrepreneurship [31].

\section{CONCLUSION}

Based on the results of the study it can be concluded as follows. The interest of student entrepreneurship in Learning the Course of Culinary Business Management in the very high category by 16 people or by $40 \%$, the high category by 24 people or by $60 \%$, the moderate category by $0 \%$, the low category by $0 \%$, and very low categories of $0 \%$. There are four strategies for developing entrepreneurial interest in Diploma students in CBM based on the achievement of entrepreneurial interest and SWOT analysis, namely the SO (Strength-Opportunity) strategy: giving students the opportunity to develop ideas and creativity, improve discipline both self-discipline and time discipline, provide opportunities, trust and responsibility of students to manage culinary business, joint evaluation after CBM practices have been further improved, WO (Weakness-Opportunity) strategy: provide opportunities to lead alternately during CBM practice, train students to take risks related to decisions that have been taken and agreed on, both the risk of a group or individual nature, provide understanding and train students to accept criticism and suggestions that are improvements or criticisms that are dropping, learning to care and correcting criticisms and suggestions proportionally, the ST (Weakness-Opportunity) strategy: providing additional knowledge and understanding of business financial management, providing understanding that learning theory actually also supports MUB learning and in the curriculum all courses are designed to provide student competency in the Food Engineering Study Program, WT (Weakness-Threat) strategy: consider providing additional leadership material or with leadership training, fostering student confidence by discussing various things / problems that exist during the CBM activities, giving survey or observation assignments to a culinary business is related to business management and financial management, so students get a real picture of managing a business. Based on the research results obtained, the suggestion that can be given is the entrepreneurial interest of students in the Diploma Study Program Culinary Engineering in the high category so that it can be suggested that more motivation is given to students to foster enthusiasm and interest in entrepreneurs, especially culinary business. The strategies for developing entrepreneurial interest in learning CBM in the Diploma Study Program Culinary Engineering can be used in the preparation of semester learning plans. The limitation in this research is that it only evaluates the optimization of business education which is carried out in learning CBM to shape the development of student entrepreneurial interest. The next research that can be done is the effectiveness of CBM learning activities.

\section{REFERENCES}

[1] L. R. Fajriah, "BPS: Jumlah Pengangguran di Indonesia Capai 6,87 Juta," Sindonews, 2018.

[2] B. G. Purnomo and T. Sukardi, "Integration of Project-Based Entrepreneurship and Productive 
Practical Learning in Vocational High Schools," J. Pendidik. Teknol. dan Kejuru., vol. 25, no. 1, 2019.

[3] T. J. Bae, S. Qian, C. Miao, and J. O. Fiet, "The Relationship Between Entrepreneurship Education and Entrepreneurial Intentions: A Meta-Analytic Review," Entrep. Theory Pract., vol. 38, no. 2, 2014.

[4] P. K. Wong, "Entrepreneurial Interests of University Students in Singapore," Technovation J., vol. 24, no. 2, pp. 163-172, 2004.

[5] N. Zuraya, "Enggartiasto: Tingkat Kewirausahaan di Indonesia Rendah," Replubika, 2018.

[6] D. Seftiawan, "630000 Orang Sarjana Masih Menganggur," Pikiran rakyat, 2018.

[7] Susilaningsih, "Pendidikan Kewirausahaan di Perguruan Tinggi: Pentingkah untuk Semua Profesi?," J. Econ., vol. 11, no. 1, 2015.

[8] A. Tittel and O. Terzidis, "Entrepreneurial Competences Revised: Developing a Consolidated and Categorized List of Entrepreneurial Competences," Entrep. Educ., vol. 3, pp. 1-35, 2020.

[9] F. Cullen, "Phenomenological Views and Analysis of Culinary Arts Students' International Internships: 'The Educational Psychology and Nature of Being' Before, During, and After International Culinary Internship," J. Culin. Sci. Technol., vol. 8, no. 2, pp. 106-126, 2010.

[10] F. J. Kuwado, "Jumlah Entrepreneur di Indonesia Jauh di Bawah Negara Maju. Kompas," kompas, 2018.

[11] A. Charney and G. Libecap, "Impact of Entrepreneurship Education, Insights," in A Kauffman Research Series, Kauffman Center for
Entrepreneurial Leadership, 2000.

[12] A. A. Gibb, "Can We Build Effective Entrepreneurship through Management Development," J. Gen. Manag., vol. 24, no. 4, pp. 1-21, 1999.

[13] G. Meredith, Kewirausahaan: Teori dan Praktek. Jakarta: PT. Pustaka Binaman Pressindo, 2000.

[14] Inkeles and D. Smith, Becoming Modern: Individual Change in Six Developing Countries. Harvard: Paperback., 1974.

[15] E. Mulyani, "Pengembangan Model Pembelajaran Berbasis Proyek Pendidikan Kewirausahaan Untuk Meningkatkan Sikap, Minat, Perilaku Wirausaha, dan Prestasi Belajar Siswa SMK," Cakrawala Pendidik. $J$., vol. xxxiii, no. 1, p. 60, 2014.

[16] Choo and Wong, "Entrepreneurial Intention: Triggers and Barriers to New Venture Creation in Singapore," Singapore Manag. Rev., vol. 28, no. 2, 2009.

[17] Slameto, Belajar dan Faktor-faktor yang Mempengaruhinya. Jakarta: Rineka Cipta, 2010.

[18] W. S. Winkel, Psikologi Pendidikan dan Evaluasi Belajar. Jakarta: PT. Gramedia Pustaka Utama, 2004.

[19] K. H. Looi and C. Khoo-Lattimore, 'Undergraduate Students' Entre preneurial Intention: Born or Made?," Int. J. Entrep. Small Bus., vol. 26, no. 1, 2015.

[20] Z. Peng, G. Lu, and H. Kang, "Entrepreneurial Intentions and Its Influencing," 2012.

[21] Hasni, "Urgensi Pendidikan Kewirausahaan dalam Menghasilkan Wirausahawan Muda dari Perguruan Tinggi," Ekspose J., vol. 17, no. 2, 2018. 
[22] W. N. A. Ibrahim, A. R. Bakar, S. Asimiran, S. Mohamed, and N. S. Zakaria, "Impact of Entrepreneurship Education on the Entrepreneurial Intentions of Students in Technical and Vocational Education and Training Institutions (TVET) in Malaysia," Int. Educ. Stud., vol. 8, no. $12,2015$.

[23] E. Purwanta, Hermanto, Sukinah, and F. Harahap, "Analisis Kebutuhan untuk Berwirausaha pada Siswa Berkebutuhan Khusus," Cakrawala Pendidik., vol. Xxxv, no. 3, 2016.

[24] N. Chihani, "A Technology Education Curriculum for Morocco: A Proposed Framework for the Public Schools and the Vocational System," Arizona State University, 1993.

[25] M. D. Condrasky, J. E. Williams, P. M. Catalano, and S. F. Griffin, "Development of Psychosocial Scales for Evaluating the Impact of a Culinary Nutrition Education Program on Cooking and Healthful Eating," J. Nutr. Educ. Behav., vol. 43, no. 6, pp. 511-516, 2011.

[26] G. Berger and A. Peerson, "Cultural Competence Lessons Learned: The Continuum Model," Med. Educ., vol. 49, no. 5, pp. 515-516, 2015.
[27] T. Pihkala, J. Vesalainen, and R. Viitala, "Motivational Background as an Explanation for Differences between Male and Female Entrepreneurship," University of Vaasa, Finland, 2003.

[28] F. Rangkuti, Analisis SWOT Teknik Membedah Kasus Bisnis. Jakarta: PT. Gramedia Pustaka Utama, 2004.

[29] P. Shinoj, SWOT Analysis for Assessing Entrepreneurship Readi ness. Training Manual on Theeranaipunya - Equipping Fisher women Youth for Future. 2016.

[30] Christianingrum and E. Rosalina, "Pengaruh Pembelajaran Kewira usahaan terhadap Minat Ber wirausaha," Integr. J. Bus. Econ., vol. 1, no. 1, 2017.

[31] N. O. Nor Hafiza Othman and N. H. Juhdi, "Entrepreneurship Education And Business Opportunity Exploitation: Positive Emotion As Mediator. Cakrawala Pendidikan," Cakrawala Pendidik., vol. 39, no. 2, 2020. 